\title{
PENERAPAN MODEL PEMBELAJARAN QUIZ TEAM UNTUK MENINGKATKAN HASIL BELAJAR EKONOMI PESERTA DIDIK KELAS XI IPS 2 SMAN 8 KEDIRI DI SEMESTER GANJIL TAHUN PELAJARAN 2018/2019
}

\author{
Rochana Ulfiati Fadilah \\ SMAN 8 Kediri \\ Rocha.fadilah@yahoo.com
}

\begin{abstract}
Economic Learning in SMAN 8 Kediri specifically in class XI IPS 2, so far it is still being agreed by the teacher. The student's questioning activity is still low. Mostly, students do not understand the concepts and the interrelationships between economic concepts. The researcher chose the Quiz Team learning method. Researchers chose the Quiz learning model because learning with the opinion of Silberman. The Quiz Team is a technique to increase participants' responsibility for what they do in a fun and non-scary way. This active learning type of Quiz Team is a technique to increase the responsibility of students towards what they improve through fun and non-frightening ways. In this study, researchers used the action research design model Kemmis and Mc. In the research design there are four stages of research namely planning (planning), action (implementation), observation (observing) and reflection (reflection). In cycle 1, researchers divided 3 large groups, A, B, and C, each group consisting of 11 students. The researcher chooses three topics which will be presented in three segments. The results of the study increased the number of students who achieved minimal completeness in each cycle. In cycle 2, researchers divided the group into smaller ones, in cycle II there were 6 groups, A, B, C, D, E and F. In cycle II, researchers divided into 6 national income calculation concepts namely the concept: Gross Domestic Product (GDP), Gross National Product (GNP), Net National Product (NNP), Net National Income (NNI), Personal Income (PI), Disposible Income (DI). Indicators Success in improving student learning outcomes in this study was seen from $80 \%$ of students completing KKM (with a value of 77). The results of the study increased the number of students who achieved minimal completeness in each cycle. At the $42 \%$ level (14) students complete KKM. In cycle 1 Approximately 61\% (20) of students have completed KKM. In cycle 2, around $82 \%$ or 26 students completed KKM. The data has increased from pre-cycle to cycle 2 .
\end{abstract}

Keywords: Learning Outcomes, Class XI IPS 2, National Revenue, Quiz Team. 


\section{A. Pendahuluan}

Pendidikan dapat dimaknai sebagai proses mengubah tingkah laku anak didik, agar menjadi manusia dewasa yang mampu hidup mandiri dalam lingkungan alam sekitar dimana individu berada. Dengan demikian pendidikan merupakan sarana dalam membangun watak bangsa melalui proses mengubah tingkah laku anak didik agar menjadi manusia dewasa yang mampu hidup mandiri dan menyesuaikan diri terhadap lingkungan tempat tinggalnya. Mulyasa mengungkapkan bahwa pendidikan memberikan kontribusi yang sangat besar terhadap kemajuan suatu bangsa dan merupakan wahana dalam menerjemahkan pesan-pesan konstitusi serta sarana dalam membangun watak bangsa. Untuk itu, pembangunan pendidikan nasional merupakan upaya bersama seluruh komponen pemerintah dan masyarakat yang dilakukan secara terencana dan sistematis untuk mewujudkan peserta didik secara aktif mengembangkan potensinya ${ }^{1}$.

Perubahan kurikulum dari tahun ke tahun merupakan kebijakan yang diambil pemerintah. Alasan pemerintah melakukan perubahan kurikulum pendidikan yang baru adalah untuk meningkatkan mutu pendidikan di Indonesia. Kurikulum yang berlaku di SMAN 8 Kediri adalah kurikulum 2013. Salah satu prinsip pelaksanaan kurikulum 2013 menurut Permendikbud No 81A tahun 2013 adalah pelaksanaan kurikulum didasarkan pada pandangan bahwa pengetahuan tidak dapat dipindahkan begitu saja dari guru ke peserta didik. Peserta didik adalah subjek yang memiliki kemampuan untuk secara aktif mencari, mengolah, mengkonstruksi, dan menggunakan pengetahuan. Untuk itu pembelajaran harus berkenaan dengan kesempatan yang diberikan kepada peserta didik untuk mengkonstruksi pengetahuan dalam proses kognitifnya. Agar benar-benar memahami dan dapat menerapkan pengetahuan, peserta didik perlu didorong untuk bekerja memecahkan masalah, menemukan segala sesuatu untuk dirinya, dan berupaya keras mewujudkan ide-idenya.

\footnotetext{
${ }^{1}$ E. Mulyasa. Manajeman Berbasis Sekolah. (Bandung: PT Remaja Rosdakarya, 2012), 4
} 
Belajar merupakan kegiatan Utama dari keseluruhan proses pendidikan di sekolah .Belajar bertujuan untuk menghasilkan perubahan tingkah laku meliputi aspek kognitif, afektif , dan psikomotorik,Kegiatan pembelajaran di kelas memerlukan adanya kreatifitas belajar siswa,partisipasi siswa dalam pembelajaran dan komunikasi interaktif siswa dengan guru. Aktivitas belajar perlu dirancang sedemikian rupa sehingga dapat mencapai tujuan pembelajaran yang telah ditentukan.Peneliti sejalan dengan pendapat,

Belajar ialah proses usaha yang dilakukan seseorang untuk memperoleh suatu perubahan tingkah 1 aku yang baru secara keseluruhan sebagai hasil pengalamannya sendiri dalam interaksi dengan lingkungannya.Perubahan yang dimaksud adalah perubaha yang terjadi secara sadar,bersifat kontinu,positif dan aktif,permanen, bertujuan dan terarah, serta mencakup seluruh aspek tingkah laku² .

Guru dalam menyampaikan materi dikelas dapat dibantu dengan menggunakan metode pembelajaran yang tepat sesuai dengan karakter mata pelajaraan yang diajarkan. Metode pembelajaran yang tepat akan menarik perhatian siswa dan mendorong munculnya partisipasi ,keaktifan serta interaksi siswa. Peniliti juga sejalan dengan pendapat Uno Hamzah, metode pembelajaran didifinisikan sebagai cara yang digunakan guru yang dalam menjalankan fungsinya merupakan alat untuk mencapai tujuan pembelajaran ${ }^{3}$.

Pembelajaran Ekonomi di SMAN 8 Kediri khususnya kelas XI IPS 2, selama ini masih didominasi oleh guru. Sementara itu peserta didik diposisikan sebagai objek. Keadaan ini tentunya menciptakan kurangnya interaksi di antara peserta didik sehingga kelas tampak pasif serta suasana belajar terkesan kaku dan membosankan. Aktivitas bertanya peserta didik masih sangat rendah, dilihat dari pertanyaan yang diajukan oleh peserta didik dan aktivitas bertanya peserta didik masih jarang bahkan peserta didik tidak mengajukan pertanyaan sama sekali. Kemampuan peserta didik dalam menanggapi atau menjawab pertanyaan dari guru pun masih sangat rendah.

\footnotetext{
${ }^{2}$ Slameto. Belajar dan Faktor-Faktor yang Mempengaruhinya. (Jakarta: PT Rineka Cipta, 2013), 5

3 Hamzah Uno. AssesmentPembelajaran. (Jakarta Bumi Aksara, 2009), 2
} 
Peserta didik kurang aktif dan cenderung bermalas-malasan seperti tidurtiduran dalam kelas, tidak mendengarkan penjelasan guru, tidak mengajukan pertanyaan ketika diberi kesempatan bertanya bahkan ada juga yang berbicara sendiri dengan teman sebangkunya.

Selain masalah di atas, masalah lain yang dapat dilihat adalah pembelajaran masih kurang efektif. Sebagian besar materi pelajaran masih dihapal peserta didik, sehingga peserta didik kurang memahami konsep dan keterkaitan antar konsep ekonomi. Pada saat peserta didik diberikan soal latihan atau pekerjaan rumah, peserta didik malas mengerjakannya, karena kurang menyenangi mata pelajaran Ekonomi. Peserta didik terlihat resah dan kurang bersemangat mengikuti pelajaran serta ingin cepat selesai ketika proses pembelajaran. Akibatnya, mempengaruhi hasil belajar yang dicapai peserta didik. Terlihat dari nilai mata pelajaran Ekonomi yang belum memenuhi Kriteria Ketuntasan Minimal (KKM) yaitu 77. Dari 33 peserta didik kelas XI IPS 2 hanya $14(42 \%)$ peserta didik yang nilainya memenuhi syarat KKM.

Jika dibiarkan terus berlangsung maka hasil belajar peserta didik semakin rendah. Peserta didik tidak akan mampu memenuhi KKM yang telah ditetapkan sekolah. Guru sebagai salah satu komponen utama dalam pembelajaran diharapkan mampu memiih dan menciptakan pembelajaran yang menyenangkan serta mengaktifkan peserta didik untuk berpartisipsi dalam mengikuti proses pembelajaran untuk meningkatkan pemahaman konsep peserta didik. Salah satu dapat diterapkan adalah model pembelajaran Quiz Team. Menurut Silberman bahwa pembelajaran aktif tipe Quiz Team ini merupakan teknik meningkatkan tanggung jawab peserta didik terhadap apa yang mereka pelajari melalui cara yang menyenangkan dan tidak menakutkan. Peneliti memilih sebuah metode pembelajaran Quiz Team ${ }^{4}$. Karena peneliti sejalan dengan menakutkan. Peneliti sejalan dengan pendapat Suprijono menjelaskan bahwa model pembelajaran Quiz Team mampu meningkatkan kemampuan siswa bertanggung jawab terhadap apa

\footnotetext{
${ }^{4}$ Melvin L. Silberman. Active Learning: 101 Strategi Belajar Mengajar. (Yogyakarta: Penerbit Ombak, 2013), 163
} 
yang mereka pelajari melalui cara yang menyenangkan dan tidak menakutkan. Model pembelajaran Quiz Team ini digunakan untuk menggerakkan diskusi, dan untuk meningkatkan kemampuan siswa dalam menentukan, menilai, dan memecahkan masalah yang dihadapi dalam kehidupannya dengan cara yang bersahabat dan menarik ${ }^{5}$.

Dalam desain penelitian tindakan model Kemmis dan Mc. Taggart terdapat empat tahapan penelitian tindakan yaitu perencanaan (planning), tindakan (implementing), pengamatan (observing ) dan refleksi (reflecting). Peneliti melakukan penelitian Tindakan Class ( Classroom Action Research ) mengacu pada model spiral Kemmis dan Mc. Taggart ${ }^{6}$.

\section{B. Model Pembelajaran Quiz Team}

Quiz Team adalah salah satu tipe dari Active learning. Active learning adalah proses pembelajaran dimana peserta didik dituntut untuk selalu aktif. Peserta didik harus aktif baik dalam hal menyampaikan pendapat ataupun memecahkan masalah yang berkaitan dengan materi yang sedang diajarkan. Peserta didik dilibatkan pada aktivitas berpikir yang lebih kompleks dimana peserta didik terlibat dan memahami apa yang mereka kerjakan. Materi yang ada dapat pula dikaitkan dengan persoalan nyata yang benar-benar terjadi dalam kehidupan sehari-hari sehingga seolah-olah mereka menjadi bagian dari hal tersebut.

Suprijono menjelaskan bahwa model ini mampu meningkatkan kemampuan siswa bertanggung jawab terhadap apa yang mereka pelajari melalui cara yang menyenangkan dan tidak menakutkan. Model pembelajaran Quiz Team ini digunakan untuk menggerakkan diskusi, dan untuk meningkatkan kemampuan siswa dalam menentukan, menilai, dan memecahkan masalah yang dihadapi dalam kehidupannya dengan cara yang bersahabat dan menarik ${ }^{7}$.

5 Suprijono. Cooperative Learning. (Yogyakarta: Pustaka Belajar, 2015), 114

6 Suharsimi Arikunto. Prosedur Penelitian Suatu Pendekatan Praktek. (Jakarta: Rineka Cipta, 2013), 3

${ }^{7}$ Suprijono. Cooperative Learning. (Yogyakarta: Pustaka Belajar, 2015), 114 
Silberman (2013) menjelaskan bahwa prosedur model Quiz Team sebagai berikut: a) guru memilih topik yang dapat dipresentasikan dalam beberapa bagian; b) peserta didik membentuk tim belajar dan masing-masing tim akan mendapatkan tugas untuk membahas satu bagian dari topik yang telah ditentukan; c) guru menjelaskan aturan main dan prosedur Quiz Team; d) guru menyajikan topik bahasan secara sekilas; e) diskusi dimulai dan tim pertama akan menyiapkan kuis jawaban singkat tentang topik yang dibahas, sementara tim lainakan menyiapkan diri dan memeriksa catatan mereka; f) kuis dimulai dengan tim pertama sebagai pemimpin kuis, tim pertama memberikan pertanyaan kepada tim kedua. Jika tim tersebut tidak dapat menjawab, tim ketiga dan seterusnya diberi kesempatan untuk segera menjawab; g) tim pertama melanjutkan kuis dengan memberikan ke pertanyaan selanjutnya kepada tim kedua laluulangi prosesnya secara bergantian; h) ketika kuis selesai, lanjutkan ke bagian kedua kuis dan tunjuklah tim kedua sebagai pemimpin kuis, ulangi proses kuis seperti pada kuis bagian pertama; i) begitu seterusnya hingga semua tim mendapat giliran.

\section{Metode Penelitian}

Penelitian ini dilaksanakan di SMAN 8 Kediri. Penelitian tindakan kelas ini dilaksanakan di kelas XI IPS 2 SMAN 8 Kediri. Peserta didik kelas XI IPS 2 berjumlah 33 peserta didik. Penelitian ini dilaksanakan pada semester ganjil tahun pelajaran 2018/2019. Penelitian ini merupakan penelitian tindakan kelas. Penelitian Tindakan Kelas merupakan suatu bentuk penelitian yang berbentuk reflektif dengan melakukan tindakan tertentu untuk memperbaiki dan meningkatkan praktik pembelajaran di kelas secara lebih berkualitas sehingga peserta didik dapat memperoleh hasil belajar yang lebih baik $^{8}$.

Penelitian ini menggunakan metode spiral dari Kemmis dan Taggart. Dalam desain penelitian tindakan model Kemmis dan Mc. Taggart terdapat empat tahapan penelitian tindakan yaitu perencanaan, tindakan, pengamatan dan refleksi. Perencanaan dalam penelitian ini yaitu peneliti menyusun

\footnotetext{
${ }^{8}$ Wina Sanjaya. Penelitian Tindakan Kelas. (Jakarta: Prenada Media, 2016), 16
} 
Rencana Pelaksanaan Pembelajaran (RPP) dengan materi pendapatan nasional. Materi ini terdapat dalam Kompetensi Dasar (KD 3.1 Memahami konsep, metode, dan manfaat perhitungan pendapatan nasional; dan 4.1 Menyajikan hasil penghitungan pendapatan nasional). RPP yang disusun menggunakan metode pembelajaran Quiz Team. Pelaksanaan pembelajaran sesuai dengan RPP yang telah disusun menggunakan metode pembelajaran Quiz Team. Proses pembelajaran dimulai dari kegiatan awal, seperti guru memberi salam dan mengajak peserta didik berdoa. Kemudian mengabsen kehadiran peserta didik, memotivasi dengan pertanyaan singkat, serta menyampaikan tujuan pembelajaran.

Kegiatan inti dimulai dari guru menjelaskan bahwa metode pembelajaran menggunakan Quiz Team. Peserta didik memilih topik yang akan disajikan dalam tiga segmen. Peserta didik dibagi ke dalam tiga kelompok besar A, B, dan C. Masing-masing kelompok berisi 11 peserta didik. Guru menyajikan materi pelajaran sekaligus menyiapkan kuis, sementara tim A, B dan tim C menggunakan waktu untuk memeriksa catatan mereka. Tim A memberikan kuis kepada tim B, jika tim B tidak dapat menjawab pertanyaan, maka soal akan di lemparkan kepada tim C. Tim A mengarahkan pertanyaan berikutnya kepada anggota tim $\mathrm{C}$, dan mengulang proses tersebut. Ketika kuisnya selesai, lanjutkan segmen kedua dari pelajaran dan mintalah tim B sebagai pemandu kuis. Setelah tim B menyelesaikan kuisnya, lanjutkan dengan segmen ketiga dari pelajaran dan tunjuklah tim C sebagai pemandu kuis. Kegiatan akhir dimulai dari guru dan peserta didik menyimpulkan hasil pembelajaran. Kemudian peserta didik mengisi lembar posttest dan guru menutup kegiatan pembelajaran.

Penelitian tindakan kelas ini bertujuan untuk melakukan peningkatan hasil belajar Ekonomi peserta didik kelas XI IPS 2 SMAN 8 Kediri. Kriteria pada penelitian ini dinyatakan berhasil apabila lebih dari $80 \%$ peserta didik kelas XI IPS 2 SMAN 8 Kediri memiliki nilai tuntas KKM (KKM 77). 


\section{Hasil Penelitian Dan Pembahasan}

Nilai hasil belajar awal peserta didik sebelum tindakan masih rendah. Hal ini diketahui setelah diadakan tes prasiklus, didapat hanya sebesar $42 \%$ peserta didik saja yang memiliki nilai tuntas KKM. Perolehan data hasil belajar tahap prasiklus dapat dilihat pada tabel berikut.

Tabel 1. Data hasil belajar prasiklus

\begin{tabular}{|c|l|c|}
\hline No & \multicolumn{1}{|c|}{ Keterangan } & Prasiklus \\
\hline 1 & Jumlah peserta didik tuntas KKM & 14 \\
\hline 2 & $\begin{array}{l}\text { Jumlah peserta didik tidak tuntas } \\
\text { KKM }\end{array}$ & 19 \\
\hline 3 & Pesentase peserta didik tuntas KKM & $42 \%$ \\
\hline 4 & Rata-rata nilai peserta didik & 70,3 \\
\hline
\end{tabular}

Berdasarkan tabel 1 diketahui hanya $42 \%$ peserta didik yang tuntas KKM atau berjumlah 14 peserta didik dari total 33 peserta didik. Data tersebut menunjukkan bahwa nilai hasil belajar peserta didik masih cukup rendah. Nilai rata-rata yang didapat dalam tes prasiklus adalah sebesar 70,3 atau masih di bawah nilai KKM. Nilai KKM yang ditetapkan dalam pelajaran Ekonomi kelas XI IPS 2 SMAN 8 Kediri adalah 77.

\section{Siklus 1}

Kegiatan pembelajaran dimulai dari membuka kegiatan pembelajaran. Guru memberi salam kepada peserta didik. Dilanjutkan dengan berdoa sebelum dimulai pelajaran. Guru mengabsen kehadiran peserta didik serta mengamati kesiapan peserta didik dalam proses pembelajaran. Guru memberikan pertanyaan-pertanyaan yang berkaitan dengan materi yang disampaikan pada hari ini untuk memotivasi peserta didik. Guru menyampaikan tujuan pembelajaran. Sebelum memulai pelajaran, guru memberitahu nilai peserta didik yang didapat dari tes prasiklus yang dilakukan pada pertemuan sebelumnya. Hanya ada $42 \%$ atau 14 peserta didik yang tuntas KKM. Guru menyarankan agar peserta didik belajar lebih baik lagi.

Kegiatan inti dimulai dari guru memberitahukan bahwa proses pembelajaran akan menerapkan metode pembelajaran Quiz Team. Guru 
menjelaskan singkat pengertian dan langkah-langkah pembelajaran metode pembelajaran Quiz Team ini. Peserta didik terlihat masih kebingungan dengan langkah-langkah metode yang dijelaskan guru. Peserta didik masih malu dan kurang percaya diri ingin bertanya kepada guru. Guru meminta peserta didik memilih topik yang akan disajikan dalam tiga segmen. Kemudian peserta didik dibagi ke dalam tiga kelompok besar A, B, dan C. Setiap kelompok berisi 11 peserta didik. Guru menyajikan materi pelajaran sekaligus menyiapkan kuis. Terlihat ada beberapa peserta didik yang tidak memperhatikan penjelasan guru. Sementara tim A, B dan tim C menggunakan waktu untuk memeriksa catatan mereka. Diskusi dimulai dan setiap tim menyiapkan pertanyaan dan jawaban singkat mengenai materi yang dibahas yang akan digunakan sebagai kuis. Guru berkeliling untuk membimbing jalannya diskusi.

Setelah selesai, tim A memberikan kuis kepada tim B, jika tim B tidak dapat menjawab pertanyaan, maka soal akan di lemparkan kepada tim C. Tim A mengarahkan pertanyaan berikutnya kepada anggota tim C, dan mengulang proses tersebut. Ketika kuisnya selesai, lanjutkan segmen kedua dari pelajaran dan mintalah tim B sebagai pemandu kuis. Setelah tim B menyelesaikan kuisnya, lanjutkan dengan segmen ketiga dari pelajaran dan tunjuklah tim $\mathrm{C}$ sebagai pemandu kuis. Terlihat peserta didik masih belum mempersiapkan diri dengan baik ketika guru akan memulai kuis antar tim. Peserta didik tampak kurang percaya diri dan takut jika kelompoknya tidak bisa menjawab pertanyaan dari kelompok lain. Ketika kuis mulai berjalan, peserta didik terlihat mulai bersemangat dalam pembelajaran tetapi masih ada yang ramai. Ketika kuis berlangsung, guru berkeliling mengawasi dan memberikan arahan ketika ada kendala. Di akhir kuis, guru mulai membahas satu persatu pertanyaan kuis yang jawabannya masih salah dan kurang tepat.

Kegiatan pembelajaran ditutup dengan guru dan peserta didik menyimpulkan hasil pembelajaran. Setelah itu guru memberikan soal posttest kepada setiap peserta didik untuk dikerjakan secara individu. Guru menutup kegiatan pembelajaran dengan salam. 
Pada siklus 1 ini jumlah peserta didik yang berani bertanya dan menjawab pertanyaan dari guru masih rendah. Sebagian dari jumlah keseluruhan peserta didik tampak antusias belajar tetapi juga beberapa peserta didik masih berbicara dengan temannya, bercanda, menyahut asal - asalan, dan bermain-main sendiri. Peserta didik belum percaya diri seperti ketika saat guru meminta untuk membacakan pertanyaan kuisnya dan menjawab pertanyaan. Belum banyak peserta didik yang aktif dalam pembelajaran. Ketika diskusi berlangsung, peserta didik tampak menghargai hasil diskusi temannya. Dalam pembelajaran tidak ditemukan peserta didik yang tidur - tiduran dan terlambat masuk kelas.

Tabel 2. Data hasil belajar siklus 1

\begin{tabular}{|c|l|c|}
\hline No & \multicolumn{1}{|c|}{ Keterangan } & Prasiklus \\
\hline 1 & Jumlah peserta didik tuntas KKM & 20 \\
\hline 2 & $\begin{array}{l}\text { Jumlah peserta didik tidak tuntas } \\
\text { KKM }\end{array}$ & 13 \\
\hline 3 & Pesentase peserta didik tuntas KKM & $61 \%$ \\
\hline 4 & Rata-rata nilai peserta didik & 77,58 \\
\hline
\end{tabular}

Berdasarkan data pada tabel 2, maka terdapat $61 \%$ (20) peserta didik yang memiliki nilai tuntas KKM di tahap siklus 1. Rata-rata nilai peserta didik di siklus 1 adalah 77,58. Berdasarkan data di atas maka hasil tes belum memenuhi indikator keberhasilan, maka penelitian dilanjutkan pada siklus selanjutnya.

Pelaksanaan pembelajaran Ekonomi sudah sesuai dengan RPP yang menerapkan metode pembelajaran Quiz Team telah selesai. Setelah dilakukan analisis terhadap nilai posttest maka didapat peningkatan nilai hasil belajar peserta didik. Pada siklus 1 peserta didik yang tuntas KKM ada $61 \%$ atau 22 peserta didik. Hal ini sudah menunjukkan perbaikan dari tahap sebelumnya. Selain itu nilai rata-rata juga meningkat menjadi 76,1 atau sudah melampaui batas KKM. Akan tetapi berdasarkan data di atas belum mencapai indikator keberhasilan, yaitu $80 \%$ peserta didik memiliki nilai di atas KKM. Oleh karena itu guru harus melakukan perbaikan pada siklus 2 supaya mencapai hasil yang lebih optimal. Refleksi hasil 
observasi pada siklus 1 dilakukan perbaikan terhadap strategi pembelajaran, RPP, dan sikap guru dan peserta didik.

Perbaikan yang perlu dilakukan pada siklus selanjutnya adalah sebagai berikut: a) guru yang menentukan materi. Hal ini dilakukan agar suasana kelas dapat kondusif daripada peserta didik yang memilih materi; b) biarkan peserta didik yang membuat pertanyaan untuk kelompok lain. Kegiatan ini dilakukan untuk melatih kemandirian peserta didik dan agar giat mempelajari materi; c) guru harus mampu mengkondisikan kelas yang ramai; d) guru berkeliling mengamati aktivitas semua peserta didik; e) guru memotivasi peserta didik untuk meningkatkan keaktifan f) peserta didik tidak boleh mengganggu kelompok lain; g) semua anggota dalam kelompok harus terlibat.

\section{Siklus 2}

Kegiatan pembelajaran dimulai dari membuka kegiatan pembelajaran. Guru memberi salam kepada peserta didik. Dilanjutkan dengan berdoa sebelum dimulai pelajaran. Guru mengabsen kehadiran peserta didik, memberikan pertanyaan-pertanyaan yang berkaitan dengan materi yang disampaikan pada hari ini untuk memotivasi peserta didik serta mengamati kesiapan peserta didik dalam proses pembelajaran. Guru menyampaikan tujuan pembelajaran. Sebelum memulai pelajaran, guru memberitahu nilai peserta didik yang didapat dari tes siklus 1 yang dilakukan pada pertemuan sebelumnya. Sudah ada $61 \%$ atau 20 peserta didik yang tuntas KKM. Guru menyarankan agar peserta didik belajar lebih baik lagi.

Kegiatan inti dimulai dari guru memberitahukan bahwa proses pembelajaran akan masih menerapkan metode pembelajaran Quiz Team. Pada siklus 2 ini guru kembali menjelaskan langkah-langkah metode pembelajaran yang diterapkan. Peserta didik terlihat memahami semua penjelasan guru. Pada siklus 2 peneliti membagi kelompok menjadi lebih kecil , pada siklus II peneliti membagi kelompok menjadi 6 kelompok, A, B, C, D, E dan F. Kelompok , A, B dan C terdiri 5 siswa, sedang 
kelompok D, E, dan F terdiri 6 siswa. Pada siklus II peneliti membagi menjadi 6 konsep perhitungan pendapatan nasional : Gross Domestic Product ( GDP), Gross National Prroduct ( GNP), Net National Product (NNP), Net National Income (NNI), Personal Income ( PI ), Disposible Income (DI),terdapat $82 \%, 26$ peserta didik tuntas KKM. Data tersebut memperlihatkan terjadi peningkatan dari prasiklus sampai siklus 2 . Guru telah menyiapkan daftar nama peserta didik dalam satu tim. Penentuan peserta didik dalam tim ini didasarkan pada kemampuan kognitif peserta didik (tinggi sedang, rendah). Peserta didik membentuk tim sesuai arahan dari guru. Tampak suasana kelas tenang dan peserta didik terlihat senang. Setiap tim mulai menyiapkan pertanyaan dan jawaban untuk kuis. Guru berkeliling membimbing jalannya diskusi. Peserta didik terlihat lebih siap dan tenang dalam menyusun pertanyaan kuisnya.

Setelah selesai, kuis antar tim dimulai. Kuis dimulai dengan tim A memberikan kuis kepada tim B, jika tim B tidak dapat menjawab pertanyaan, maka soal akan dilemparkan kepada tim C. Jika tim C tidak dapat menjawab tim A mengarahkan pertanyaan berikutnya kepada anggota tim D, bila tim D tidak dapat menjawab tim A akan mengarahkan pertanyaan kepada tim $\mathrm{E}$, bila tim E jugat tidak dapat menjawab maka tim A mengarahkan pertanyaan kepada tim F. Ketika kuisnya selesai, lanjutkan konsep kedua dari pelajaran dan mintalah tim B sebagai pemandu kuis. Setelah tim B menyelesaikan kuisnya, dilanjutkan dengan konsep ketiga dari pelajaran dan ditunjuklah tim $\mathrm{C}$ sebagai pemandu kuis.Pada konsep keempat tim D sebagai pemandu Quis. Pada konsep kelima tim E sebagai pemandu Quiz untuk konsep yang keenam tim F sebagai pemandu kuis. Jalannya kuis tampak lancar dan semua peserta didik terlihat aktif dan bersemangat menjawab kuis dari tim lain. Ketika kuis berlangsung, guru berkeliling mengawasi dan memberikan arahan ketika ada kendala. Di akhir kuis, guru membahas satu persatu pertanyaan kuis yang jawabannya masih salah dan kurang tepat. Guru juga memberikan pertanyaan-pertanyaan lain kepada peserta didik untuk menguatkan dan memperluas pemahaman materi. 
Kegiatan pembelajaran ditutup dengan guru menyampaikan rencana pembelajaran pada pertemuan berikutnya. Setelah itu, guru memberikan soal posttest kepada setiap peserta didik untuk dikerjakan secara individu. Sebelum menutup kegiatan pembelajaran, guru dan peserta didik bertanya jawab singkat dengan peserta didik terkait materi yang telah dipelajari. Guru menutup kegiatan pembelajaran dengan salam.

Pada siklus 2 ini jumlah peserta didik yang berani bertanya dan menjawab pertanyaan dari guru sudah tinggi. Sebagian dari jumlah keseluruhan peserta didik tampak antusias belajar, hanya sedikit peserta didik yang berbicara dengan temannya, bercanda, menyahut asal - asalan, serta bermain - main sendiri. Peserta didik sudah percaya diri ketika guru meminta membacakan jawabannya. Peserta didik juga sudah aktif saat diskusi dan mau menanggapi teman yang lain saat presentasi. Tidak ditemukan peserta didik yang tidur-tiduran dan terlambat masuk kelas dalam siklus 2 ini.

Tabel 3. Data hasil belajar siklus 2

\begin{tabular}{|c|l|c|}
\hline No & \multicolumn{1}{|c|}{ Keterangan } & Prasiklus \\
\hline 1 & Jumlah peserta didik tuntas KKM & 27 \\
\hline 2 & $\begin{array}{l}\text { Jumlah peserta didik tidak tuntas } \\
\text { KKM }\end{array}$ & 6 \\
\hline 3 & Pesentase peserta didik tuntas KKM & $82 \%$ \\
\hline 4 & Rata-rata nilai peserta didik & 85,45 \\
\hline
\end{tabular}

Berdasarkan data pada tabel 3, maka terdapat $82 \%$ (27) peserta didik yang memiliki nilai tuntas KKM di tahap siklus 2. Rata-rata nilai peserta didik di siklus 1 adalah 85,45 atau sudah di atas nilai KKM. Berdasarkan data di atas maka hasil tes telah memenuhi indikator keberhasilan, maka penelitian dihentikan pada siklus 2 ini.

Berdasarkan hasil observasi yang dilakukan pada siklus 2, pelaksanaan pembelajaran Ekonomi sudah sesuai dengan RPP yang menerapkan metode pembelajaran Quiz Team telah selesai. Setelah dilakukan analisis terhadap nilai posttest maka didapat peningkatan nilai hasil belajar peserta didik. Pada siklus 2 peserta didik yang tuntas KKM ada $82 \%$ atau 27 peserta didik. Hal ini sudah menunjukkan perbaikan dari 
tahap sebelumnya. Selain itu nilai rata-rata juga meningkat menjadi 85,45 atau sudah melampaui batas KKM. Berdasarkan data observasi terhadap kegiatan pembelajaran, observer masih memberikan beberapa masukan yang dapat dijadikan acuan untuk meningkatkan kualitas pembelajaran.

Pelaksanaan pembelajaran pada siklus 2 sudah sesuai dengan RPP, juga termasuk alokasi waktu sudah baik. Metode pembelajaran yang digunakan efektif. Guru sudah membimbing dengan baik. Guru telah berhasil memotivasi peserta didik untuk berani bertanya. Peserta didik nampak senang dan antusias belajar dengan diterapkan metode pembelajaran ini.

\section{Pembahasan}

Penelitian tindakan kelas ini difokuskan untuk membuktikan apakah ada peningkatan pada hasil belajar Ekonomi melalui penerapan metode pembelajaran Quiz Team bagi peserta didik kelas XI IPS 2 SMAN 8 Kediri. Dengan analisis ini akan diketahui apakah terjadi peningkatan hasil belajar peserta didik dalam setiap siklus PTK atau tidak, dengan cara melihat ketercapaian peserta didik dalam KKM yaitu 77. Untuk mengetahui persentase ketercapaian KKM peserta didik di setiap siklus, rumus yang digunakan adalah:

$$
\frac{\text { jumlah peserta didik tuntas KKM }}{\text { jumlah peserta didik keseluruhan }} \times 100 \%
$$

Tabel. 4. Rekapitulasi nilai hasil belajar peserta didik

\begin{tabular}{|c|l|c|c|c|}
\hline No & \multicolumn{1}{|c|}{ Keterangan } & Prasiklus & Siklus 1 & Siklus 2 \\
\hline 1 & Jumlah peserta didik tuntas & 14 & 20 & 27 \\
\hline 2 & Jumlah peserta didik tidak tuntas & 19 & 13 & 6 \\
\hline 3 & Persentase peserta didik tuntas & $42 \%$ & $61 \%$ & $82 \%$ \\
\hline 4 & Rata-rata nilai peserta didik & 70,3 & 77,58 & 85,45 \\
\hline
\end{tabular}

Tabel 4 memperlihatkan kenaikan jumlah peserta didik yang mencapai ketuntasan minimal di setiap siklus. Pada tahap prasiklus terdapat $42 \%$ peserta didik yang memiliki nilai tuntas KKM. Jumlah peserta didik yang tuntas pada tahap prasiklus adalah 14 peserta didik dan 19 peserta didik tidak tuntas 
KKM. Nilai rata-rata pada prasiklus adalah 70,3 atau masih di bawah nilai KKM, yaitu 77.

Tahap prasiklus hanya 14 dari 33 peserta didik yang tuntas. Kemudian pada siklus 1 meningkat menjadi 20 dari 33 peserta didik yang tuntas. Lalu pada siklus 2 kembali meningkat menjadi 27 dari 33 peserta didik yang tuntas. Persentase pada tahap prasiklus hanya $42 \%$ peserta didik yang tuntas. Pada siklus 1 ketuntasan meningkat menjadi 61\%, dan pada siklus 2 kembali meningkat menjadi $82 \%$ peserta didik yang tuntas.

Nilai rata-rata yang didapat peserta didik dalam setiap siklus. Pada prasiklus nilai rata-rata peserta didik adalah 70,3 atau di bawah KKM. Pada siklus 1 nilai rata-rata peserta didik adalah 77,58 atau di atas KKM. Pada siklus 2 nilai rata-rata peserta didik meningkat menjadi 85,45 atau di atas KKM.

Pada proses penelitian siklus 1, guru menerapkan model Quiz Team dalam proses pembelajaran Ekonomi. Proses pembelajaran dimulai dari guru menjelaskan bahwa model pembelajaran menggunakan Quiz Team. Peserta didik memilih topik yang akan disajikan dalam tiga segmen. Peserta didik dibagi ke dalam tiga kelompok besar A, B, dan C. Masing-masing kelompok berisi 11 peserta didik. Guru menyajikan materi pelajaran sekaligus menyiapkan kuis, sementara tim A, B dan tim C menggunakan waktu untuk memeriksa catatan mereka. Tim A memberikan kuis kepada tim B, jika tim B tidak dapat menjawab pertanyaan, maka soal akan di lemparkan kepada tim C. Tim A mengarahkan pertanyaan berikutnya kepada anggota tim $\mathrm{C}$, dan mengulang proses tersebut. Ketika kuisnya selesai, lanjutkan segmen kedua dari pelajaran dan mintalah tim B sebagai pemandu kuis. Setelah tim B menyelesaikan kuisnya, lanjutkan dengan segmen ketiga dari pelajaran dan tunjuklah tim $\mathrm{C}$ sebagai pemandu kuis. Guru mengevaluasi pembelajaran. Kemudian diakhiri dengan peserta didik mengerjakan soal posttest.

Setelah dilakukan pembelajaran selama 3 kali pertemuan di tahap siklus 1 dengan menerapkan metode pembelajaran Quiz Team nilai hasil belajar menunjukkan peningkatan. Hal ini terlihat dari persentase peserta didik yang tuntas KKM adalah $61 \%$ peserta didik tuntas KKM. Pada siklus 1 
terdapat 20 peserta didik tuntas KKM dan 13 peserta didik tidak tuntas KKM. Hal ini menunjukkan peningkatan, meskipun belum mencapai indikator keberhasilan, yaitu $80 \%$ peserta didik tuntas KKM.

Namun beberapa permasalahan di atas kemudian diperbaiki pada siklus 2. Kegiatan pembelajaran di siklus 2 dimulai dari guru menjelaskan bahwa metode pembelajaran menggunakan Quiz Team kemudian memilih topik yang akan disajikan dalam enam konsep . Peserta didik dibagi ke dalam 6 kelompok ,kelompok A, B, dan C berisi 5 peserta didik,sedang kelompok D,E dan F terdiri 6 peserta didik .Guru menyajikan materi pelajaran. Guru meminta tim A untuk menyiapkan kuis jawaban singkat, sementara tim B ,C ,D ,E dan tim F menggunakan waktu untuk memeriksa catatan mereka. Peserta didik diberikan kesempatan bertanya mengenai materi. Tim A memberikan kuis kepada tim B, jika tim B tidak dapat menjawab pertanyaan, maka soal akan di lemparkan kepada tim C. jika tim C tidak dapat menjawab pertanyaan, maka soal akan di lemparkan kepada tim D jika tim D tidak dapat menjawab pertanyaan, maka soal akan di lemparkan kepada tim E jika tim E tidak dapat menjawab pertanyaan, maka soal akan di lemparkan kepada tim F,dan mengulang proses tersebut. Ketika kuisnya selesai, melanjutkan konsep kedua dari pelajaran dan mintalah tim B sebagai pemandu kuis. Setelah tim B menyelesaikan kuisnya, melanjutkan dengan konsep ketiga dari pelajaran dan tunjuklah tim C sebagai pemandu kuis. Setelah tim C selesai memandu Quiz,

Dilanjutkan oleh tim D sebagai pemandu Quiz konsep yang keempat setelah menyelesaikan kuisnya, selanjutkan tim E sebagai pemandu Quis konsep yang kelima dari pelajaran .Berikutnya ditunjukllah tim $\mathrm{F}$ sebagai pemandu Quiz konsep yang ke 6 dari pelajaran. Guru memberikan kesimpulan dan menjelaskan kembali materi apabila ada jawaban peserta didik yang kurang benar. Kegiatan pembelajaran diakhiri dengan peserta didik mengerjakan soal post test.

Setelah dilakukan pembelajaran selama 3 kali pertemuan di tahap siklus 2 dengan menerapkan metode pembelajaran Quiz Team nilai hasil belajar menunjukkan peningkatan. Hal ini terlihat dari persentase peserta didik yang tuntas KKM adalah $82 \%$ peserta didik tuntas KKM. Pada siklus 2 
terdapat 27 peserta didik tuntas KKM dan 6 peserta didik tidak tuntas KKM. Hal ini menunjukkan peningkatan, dan telah mencapai indikator keberhasilan, yaitu lebih dari $80 \%$ peserta didik memiliki nilai tuntas KKM.

Pembelajaran dengan menggunakan model pembelajaran Quiz Team dapat dijadikan salah satu alternatif untuk meningkatkan hasil belajar peserta didik terhadap pelajaran sehingga pembelajaran berjalan dengan lebih baik dan optimal. Oleh karena itu, metode pembelajaran ini disarankan untuk diterapkan oleh guru dalam proses pembelajaran karena memberikan daya tarik peserta didik untuk belajar lebih sungguh-sungguh. Penggunaan model pembelajaran Quiz Team dapat meningkatkan nilai hasil belajar peserta didik kelas XI IPS 2 SMAN 8 Kediri dalam pelajaran Ekonomi materi pendapatan nasional di semester ganjil tahun pelajaran 2018/2019.

\section{E. Kesimpulan}

Pembelajaran Ekonomi di SMAN 8 Kediri khususnya kelas XI IPS 2, selama ini masih didominasi oleh guru. Keadaan ini tentunya menciptakan kurangnya interaksi di antara peserta didik sehingga kelas tampak pasif serta suasana belajar terkesan kaku dan membosankan. Aktivitas bertanya peserta didik masih sangat rendah, dilihat dari pertanyaan yang diajukan oleh peserta didik dan aktivitas bertanya peserta didik masih jarang bahkan peserta didik tidak mengajukan pertanyaan sama sekali. Peserta didik kurang aktif dan cenderung bermalas-malasan. Sebagian besar materi pelajaran masih dihapal peserta didik, sehingga peserta didik kurang memahami konsep dan keterkaitan antar konsep ekonomi. Pada saat peserta didik diberikan soal latihan atau pekerjaan rumah, peserta didik malas mengerjakannya, karena kurang menyenangi mata pelajaran Ekonomi. Akibatnya, mempengaruhi hasil belajar yang dicapai peserta didik.

Perbaikan proses pembelajaran dapat dilakukan dengan menerapkan strategi pembelajaran yang sesuai. Salah satu strategi yang dapat mengatasi masalah tersebut adalah dengan menerapkan model pembelajaran aktif Quiz Team. Strategi pembelajaran ini bertujuan untuk memberikan dampak positif bagi peserta didik dalam menerima materi yang dibahas. Penggunaan model 
pembelajaran aktif Quiz Team diharapkan dapat meningkatkan kemampuan menyelesaikan soal secara kritis dan membiasakan peserta didik untuk bersaing secara sehat. Dengan demikian peserta didik akan lebih menghargai dan menerima satu sama lain sehingga peserta didik akan lebih percaya diri. Peserta didik akan tertantang dan bersemangat untuk bekerjasama menjawab soal yang diberikan karena ingin menjadi tim yang terbaik.

Berdasarkan seluruh kegiatan penelitian tindakan kelas yang dilakukan di kelas XI IPS 2 SMAN 8 Kediri pada pelajaran Ekonomi materi pendapatan nasional di semester ganjil tahun pelajaran 2018/ 2019 dapat disimpulkan bahwa penelitian tindakan kelas dengan menerapkan model pembelajaran Quiz Team dapat meningkatkan hasil belajar peserta didik. Hal ini terbukti dari peningkatan nilai rata-rata hasil belajar peserta didik sebelum tindakan yang menunjukkan rata-rata sebesar 70,3. Kemudian pada siklus 1 meningkat menjadi 77,58. Kemudian meningkat kembali pada siklus 2 yaitu menjadi 85,45. Persentase ketuntasan belajar sebelum dilaksanakan tindakan adalah 14 dari 33 peserta didik yang nilainya tuntas KKM mencapai (42\%). Setelah dilakukan tindakan, ketuntasan klasikal meningkat menjadi 20 dari 33 peserta didik yang nilainya tuntas KKM mencapai (61\%) pada siklus 1 . kemudian pada siklus 2 ketuntasan kembali meningkat menjadi 27 dari 33 peserta didik yang nilainya tuntas KKM mencapai (82\%). Hal ini sudah memenuhi indikator keberhasilan yaitu lebih dari $80 \%$ nilai peserta didik tuntas KKM. Nilai KKM yang ditetapkan pada pelajaran Ekonomi kelas XI IPS 2 adalah 77.

Dapat disimpulkan bahwa model pembelajaran Quiz Team mampu meningkatkan hasil belajar peserta didik kelas XI IPS 2 SMAN 8 Kediri pada pelajaran Ekonomi materi pendapatan nasional di semester ganjil tahun pelajaran 2018/2019. 


\section{Daftar Pustaka}

Arikunto, Suharsimi. Prosedur Penelitian Suatu Pendekatan Praktek. Jakarta: Rineka Cipta, 2013.

Mulyasa, E. Manajeman Berbasis Sekolah. Bandung: PT Remaja Rosdakarya, 2012.

Sanjaya, Wina. Penelitian Tindakan Kelas. Jakarta: Prenada Media, 2016.

Silberman, Melvin L. Active Learning: 101 Strategi Belajar Mengajar. Yogyakarta: Penerbit Ombak, 2013.

Suprijono. Cooperative Learning. Yogyakarta: Pustaka Belajar, 2015.

Slameto. 2013. Belajar dan Faktor-Faktor yang Mempengaruhinya. Jakarta: PT Rineka Cipta.

Uno, Hamzah, AssesmentPembelajaran. Jakarta: Bumi Aksara, 2009. 